\title{
Transparency, participation, and accountability practices in open government: A comparative study \\ by Djoko Sigit
}

Submission date: 19-Mar-2019 09:37PM (UTC-0700)

Submission ID: 1096447847

File name: parency,_participation,_and_accountability_practices_in_open.pdf (1.14M)

Word count: 13869

Character count: 78092 


\title{
Transparency, participation, and accountability practices in open government: A comparative study
}

\author{
Teresa M. Harrison ${ }^{\text {a,* }}$, Djoko Sigit Sayogo ${ }^{\text {b,c, } 1}$ \\ a Department of Communication, University at Albany, 1400 Washington Ave., Albany, NY 12222, USA \\ ${ }^{b}$ Center for Technology in Government, University at Albany, Albany, NY 12222, USA \\ c Department of Economics, University of Muhammadiyah at Malang, Jl. Raya Tlogomas No. 246, Malang 65112, Indonesia
}

\section{A R T I C L E I N F O}

Available online 12 October 2014

\section{Keywords:}

Budget transparency

Participation

Accountability

Budget disclosure

Open government

Open Government Partnership

Fiscal affairs

\begin{abstract}
A B S T R A C T
In a comparative national study addressing the fiscal domain, we explored relationships between socio-cultural, political, economic, and government conditions and concepts critical to open government, defined as (a) budget transparency (b) participation in budget processes, and (c) accountability information. We found that democracy, 4 han capital, and budget document disclosures are consistently related to transparency, accountability, and the involvement of the Supreme Audit Authority with the public. E-participation and commitment to the Open Government Partnership are each related to particular measures of transparency and accountability. Gross domestic product was negatively related to particular measures of transparency and accountability. Only democracy was related to public participation in budget discussions with the executive, and that was a minimal effect.

(C) 2014 Elsevier Inc. All rights reserved.
\end{abstract}

\section{Introduction}

In a representative democracy, legitimacy is based upon citizens' trust that elected representatives and government administrators are implementing the will of the people (Tyler, 1998). Such trust is built and sustained by a complex of relations between information, transparency, accountability, and participation. Political and information theorists alike have acknowledged that democracies depend on information in order to function. It is the coin of the realm in democratic systems, according to Norris (2001); "[g]ood information" is required for "good democracy" (Dervin, 1994). There are "myriad" ways in which information is vital to democracy (Bimber, 2003): information enables citizens to formulate preferences among policy options, agencies to administer laws and regulations, and government in general to engage in "the mechanisms of accountability that freshen democracy and sustain its legitimacy" (Bimber, 2003, p. 11, see also Bowie, 1990).

Information transparency describes a condition in which citizens have access to the data and documents that bear upon actions and decisions taken by government actors (Florini, 2007). Information so provided becomes instrumental to enabling citizens to detect corruption and hold their governments accountable (McGee \& Gaventa, 2011;

\footnotetext{
* Corresponding author.

E-mail addresses: tharrison@albany.edu (T.M. Harrison), dsayogo@ctg.albany.edu, idsayogo@gmail.com, djoko_s@umm.ac.id, dsayogo@umm.ac.id (D.S. Sayogo).

1 This author's second address is a permanent address.
}

Michener \& Bersch, 2013). In democracies where citizens delegate authority for decision making, transparency and accountability function together to produce the information that citizens need to assess and validate the actions of their governments, thus providing an ongoing basis for consent of the governed. Public participation supplements these processes in that the public is viewed as the ultimate audience for and consumer of information provided through transparency processes (Heald, 2012; Michener \& Bersch, 2013); indeed, information is an essential ingredient in genuine 3 lic participation (Arnstein, 1969).

Democratic governments often fall short of fulfilling the expectations of their citizens, giving rise to demands for transparency, which has been described as a remedy "for the deficiencies and operations of government where government claims to be democratic but where it falls short of its rhetoric" (Birkinshaw, 2006, p. 48). Contemporary calls to "open" governments around the world through transparency, participation, and accountability may be heard as efforts to insure that routine and daily government processes produce actions, services, and products that are publicly accessible and viewed by citizens as representing the substance as well as the appearance of democracy. On the heels of the Obama Administration's "open government" initiative for the U.S. federal bureaucracy (Obama, 2009), the U.S. State Department launched the Open Government Partnership (OGP, see http://www.opengovpartnership.org) in fall 2011, an international effort to strengthen democracies around the world by cultivating transparency, participation, and accountability in governance. Admission to the Partnership requires countries to document that a legal basis exists for citizens' access to information. Beyond this legal foundation, nations are asked to commit themselves to a plan for activities over time that 
promote the development of transparency, participation, and accountability at the federal/national level. At the time we write, 60 countries around the world have created or are in the process of creating such commitments, and, of these, 38 have implemented their national plans.

Transparency in the context of fiscal affairs is a particularly important indicator of a government's commitment to opening its internal decision making processes. Through fiscal transparency - information about budgets, audits, and related financial policies - citizens are able to make demands for government action, apply pressure for performance improvements, and evaluate the efficacy of administrative action. While few citizens may be interested in and even fewer knowledgeable about national government budgets, budgets are nonetheless critical documents for democratic governance (Heald, 2012). In democracies, a distinction is made between what belongs to the state and what belongs to the sovereign or ruler, something that "is understood in most industrial democracies but not in many other countries with baleful effects on the fiscal domain" (Heald, 2012, p. 36). Because public budgets are based on financial contributions from citizens and assets that are publicly owned, citizens have the right to budgetary transparency, participation, and accountability. Such was the opinion of more than one hundred civil society organizations representing 56 countries, which endorsed these rights by signing the Dar es Salaam Declaration of Budget Transparency, Accountability, and Participation. The Declaration asserted that "[p]ublic budgets must be transparent, meaning that all information related to the way in which public money is raised, allocated, spent and accounted should be made available to the general public in an accessible, timely and comprehensible way" (First Global Assembly for Budget Transparency, Accountability and Participation, 2012). Further, in decisions related to the creation and adoption of public budgets, participation is a "fundamental right and responsibility of all citizens" (First Global Assembly for Budget Transparency, Accountability and Participation, 2012). There is general internationa agreement about the importance of budget information as key to good governance, since budgets are "the single most important policy document of governments, where policy objectives are reconciled and implemented in concrete terms" (OECD, 2002). Accordingly, nations seeking to join the OGP are asked to demonstrate budgetary transparency through their scores on the Open Budget Survey (see http:// internationalbudget.org/what-we-do/open-budget-survey/), an instrument that assesses the disclosure of fundamental budget documents as well as the extent to which disclosure involves critical and timely information, actions that promote citizen participation in budget policy, and a variety of reporting practices that constitute accountability (Open Government Partnership, n.d.). The Survey, discussed further below, is administered by the International Budget Partnership (see http:// internationalbudget.org/).

Thus, transparency, participation, and accountability are interdependent cornerstones of open and democratic government. However, transparency may be accorded with some conceptual primacy since without information related to a policy domain, no further actions related to participation and accountability can take place. Perhaps because of this fundamental importance, scholars have begun to inquire more closely about what is meant by "transparency," how the term is used, and how transparency relates to participation and accountability (Bannister \& Connolly, 2011; Grimmelikhuijsen, 2013; Michener \& Bersch, 2013), as we will discuss further below. While disclosure is at the heart of transparency, simple disclosure does not begin to address more complex questions about transparency: What specific information is disclosed in transparency processes, and under what conditions? At what point in the budgeting process does disclosure takes place, and what factors predict transparency timeliness? As Michener and Bersch (2013) have pointed out, transparency is often used as an independent variable to explain conditions such as corruption, but is less frequently examined as a condition to be explained. Further, although transparency, participation, and accountability are conceptually related and may co-occur in practice as well, it is not clear whether the factors that predict fiscal transparency are also likely to predict fiscally related participation and accountability practices as well. At this time, we have little understanding of whether the broad socio-cultural, political, and economic conditions that theory suggests are related to fiscal transparency are similarly related to national processes of fiscally related participation and accountability practices.

Beyond these questions, two more government attributes may be associated with fiscally-related transparency, participation and accountability practices, as we discuss further below. First, recent efforts to use e-government mechanisms may be successful in increasing levels of transparency, participation, and accountability, as many of their advocates hope (see discussion below). Second, nations that pursue membership in the Open Government Partnership express their goals of improving fundamental processes of transparency, participation, and accountability between governments and their citizens. It seems relevant to inquire whether innovations in e-government and membership in a global effort to increase legitimacy and trust in government are related to transparency, participation, and accountability in fiscal affairs.

3 Thus, our goal is two-fold: we wish to explore the national level socio-cultural, political, economic, and government conditions that may predict fiscally-related transparency, participation, and accountability, with information about national budgets as the focal policy domain. We also wish to improve our understanding of the differences between fiscal transparency, participation, and accountability as they relate to open government. In a comparative international study, we examine national conditions that are thought to be related to (a) budget transparency, (b) public participation in budget processes, and (c) accountability.

The remainder of this paper is organized into five additional sections. In Section 2, we review theory and research related to a finer conceptualization of transparency, participation, and accountability and in Section 3, we discuss socio-cultural, political, economic, and government factors that research and reasoning suggests are related to these characteristics. In Section 4, we describe our research methods, including operational definitions of our independent variables and a description of our dependent variables, which are composite measures based upon Open Budget Survey data collected by the International Budget Partnership. In Section 5, we present a series of regression analyses undertaken to assess the relationships between these measures of budgetary transparency, participation, and accountability and the factors that we expect to predict them. We conclude by reflecting on the strong role of democracy and education in predicting transparency and accountability, and the interesting contributions that e-participation and membership in the OGP appear to be making. We further conclude that while transparency and accountability are predicted in similar ways in our analyses, it appears that public participation differs substantially.

\section{Transparency, participation and accountability}

2

Cals for transparency have recently become more urgent, i 2 bart because new information and communication technologies (ICTs), used in support of both e-government as well as open government initiatives, have made it increasingly feasible to disseminate information. ICT, it is argued, increases the scope and reach of transparency at less expense, and potentially creates new opportunities for participation and accoun 2 ility (Bertot, Jaeger, \& Grimes, 2010; Fung, 2006; Margetts, 2006). E-government and social media, in particular, can be used to make public records more widely available, reduce corruption by preventing price fixing, decrease the opportunities for bribes, and provide opportunities for whistle blowing and exposing corruption, although there are admittedly readiness issues to overcome in achieving these goals (Bertot et al., 2010). Still, these prospects are exciting, and give rise to ambitious plans. For example, the Sunlight Foundation's 2013 "transparency agenda" calls for "real time, online disclosure for 
lobbying" along with transparency about tax expenditures, federal contracts, and the budget process in general. These actions are viewed as feasible since " $[t]$ he internet is making increased transparency cheaper, more effective, and in more demand every day as Americans come to expect instantaneous and constant access to all kinds of information" (Sunlight Foundation, 2013).

However, while ICTs make the distribution of information seemingly cheaper and more feasible than ever, these very capabilities have prompted scholars to think more critically about what is meant by transparency, acknowledging that the concept is more complex than has been traditionally recognized. Several recent studies (Bannister \& Connolly, 2011; Dawes, 2010; Grimmelikhuijsen, 2013) take issue with the claim that more transparency is necessarily better, suggesting that policymakers consider what "e-transparency" would realistically entail. As a conduit, ICT promises swifter and potentially more complete transmission and distribution of information, but little consideration has been given to the costs of such an enterprise from technical and privacy perspectives; the dangers of inadvertent distribution; and the difficulties of discriminating between useful information and that which drowns its recipients in irrelevant documents (Bannister \& Connolly, 2011; Dawes, 2010; Grimmelikhuijsen, 2013). Further, realtime e-transparency may have the effect of stimulating a "non-recording" culture characterized by political correctness and defensive thinking (Bannister \& Connolly, 2011), especially if accompanied by a "gotcha" psychology focused largely on blame (Fung \& Weil, 2010; Grimmelikhuijsen, 2013).

\subsection{Complicating what is meant by transparency}

The conversation about transparency has been driven partially by the need to determine what information is useful and when, and what is not. Scholars have puzzled over how to differentiate in principle between information that contributes to effective transparency and simple disclosure of information that may obscure important issues, frustrating citizens' efforts to find what they need. For example, Fung, Graham, and Weil (2007) advocate a form of "targeted transparency" that suggests that information provided through transparency policy must be defined within particular contexts of use and through laws and policies that compel particular kinds of disclosure (see also Fung \& Weil, 2010).

Similarly, instead of choosing between more versus less transparency, Heald (2006) suggests distinguishing among a set of variations on the theme of transparency. He differentiates between event oriented transparency, which focuses on disclosure at points in time or states that are "externally visible, and - at least in principle - measurable" and process transparency, which can become politicized, damage organizational effectiveness, and induce defensive behavior (p. 31). He prefers transparency in retrospect as opposed to real-time transparency because the former permits an organization to do business, releasing performance information at periodic intervals during a reporting cycle, while the latter implies continuous surveillance (p. 32-33). Heald (2006) also urges sensitivity to the distinction between what he calls nominal transparency, in which indicators provide assessments of transparency, and effective transparency, which requires a number of components, one of which is the "disciplined" release of information, consisting of "comprehensive coverage and a well-designed hierarchy of reporting documents" (2012, p. 45). Michener and Bersch (2013, p. 238) not only agree on the need for "visibility" in transparency processes, which refers to "a high degree of completeness" in the information provided about a domain of action, but also advocate the quality of "infer-ability" which refers to the ability of third parties to draw "verifiable inferences," which they assume to be the intended audience or consumers of information. This last point suggests that transparency as a process yields products that are intended for consumption by relevant audiences.
2.2. Conceptual interdependencies between transparency, participation, and accountability

In elaborating on what is key to the creation of what he calls effective transparency, Heald (2012) agrees on the need to consider audience. He has called attention to the need for a skilled audience, capable of consuming the information provided through transparency, suggesting the importance of participation. Other requirements focus on a public audit, which he views as "vital" to effective transparency by validating financial reporting, authorizing expenditure, and documenting performance and the absence of fraud and corruption. Thus, Heald's suggestions for fiscal transparency point to transparency practices that are: (1) comprehensive and (2) disciplined or regular in their appearance, as we might expect, but that are also (3) accompanied by audits, and (4) directed at knowledgeable audiences. Pérez et al.'s (2005) model of fiscal transparency for e-government, based on standards provided by the Financial Accounting Standards Board and the American Institute of Certified Public Accountants, encompasses similar suggestions with respect to the completeness of financial information, audited information, and the assumption that an audience will consume this information. While their focus is directed squarely on transparency and its completeness and timeliness beyond simple disclosure, it is clear from these suggestions that public participation and knowledgeable engagement, as well as financial accountability in the form of regular audits, are both critical elements of the transparency policies that are advocated.

Thus, in the fiscal domain, transparency is conceptually bound to participation and accountability, with all three integral requirements for open gover 5 ent Khagram, De Renzio, and Fung (2013) agree, but point out that, while transparency is a pre-condition for participation and accountability, it is not the case that participation and accountability inevitably follow the achievement of transparency reforms. They note that "the links between fiscal transparency, participation, and accountability are often weak, interrupted, incomplete, or, in the best of cases, difficult to unearth and explain and dependent on idiosyncratic factors" (p. 39). Transparency is easier to achieve than participation; further, the achievement of participation does not insure the achievement of accountability (Khagram et al., 2013). Thus it is important to consider if factors related to transparency are also related to participation and accountability as separate and essential democratic features in their own right.

Indeed, noting that citizen engagement in policy making is a "core element" of good governance, and acknowledging that information is an essential precondition for citizen engagement, the OECD (2001) distinguishes between consultation, in which citizens are asked for their opinions about issues that government defines for them, and active participation, in which citizens help to set the agenda, propose policy, and shape the dialogue (OECD, 2001). Actions and decisions produced through public participation are likely to prove more effective (Kweit \& Kweit, 1981), enhance perceptions of legitimacy and justice (Fung, 2006) and cultivate the capacity for fair and informed deliberation (Sirianni, 2009).

Participation in fiscal affairs can be achieved in a number of different ways. It may consist of enabling other government bodies, such as legislatures, to examine budgets and provide input about resource distribution and budget priorities. It may also involve public participato 5 budgeting, the most famous example of which has taken place in Porto 5 gre, Brazil, where, initiated in the midst of transparency reforms, community representatives are able to express their priorities for public investment; the experience has increased citizen's capacities to understand and challenge public expenditures (Alves \& Heller, 513). This model has been exported to other municipalities in Brazil, Great Britain, Germany, Italy, and the U.S. (Lerner, 2011, 2012; Peixoto, 2009).

The meaning of the term accountability varies with context, but in public administration, it refers to the obligation of government to 
answer to its citizens usually by reporting information about the use of public resources in ways that enable citizens to assess its performance (Louren 0, 2013; Wong \& Welch, 2004). Scholars have suggested that effective fiscal accountability processes improve perceptions of legitimacy, curtail fraud and corruption, increase fiscal responsibility among government actors, improve the public's understanding of why performance goals may not be met, and ultimately help to establish trust (Benito \& Bastida, 2009, Curtis \& Meier, 2006; Ferraz \& Finan, 2008; Halachmi \& Holzer, 2010).

\section{Hypothesis development}

As described above, and in contrast to simple disclosure, transparency practices related to completeness and timeliness, along with participation and accountability, are recommended by those interested in opening government, but relatively little is known about the conditions that contribute to the appearance of each of these within diverse national contexts. To some extent, this has been due to difficulties in creating valid and reliable measures of fiscal transparency that can be used across governmental contexts. However, the Open Budget Survey (OBS), created by researchers affiliated with the International Budget Partnership (IBP), has creatively addressed this problem. Our dependent variables consist of transparency, participation, and accountability measures modeled specifically on the discussion above that are based on items from the Open Budget Survey (see below). We sought to assess several national level factors that may be expected to be related to particular measures of transparency, participation, and accountability as well as several government factors that may bear on contemporary efforts to promote open government goals. Below we describe the variables included in our model, and their associated rationales.

\subsection{Key socio-cultural, political, economic, and government predictors}

Research has identified a few key socio-cultural, political, and economic factors that appear to be consistently related to transparency (Khagram et al., 2013). Of these we focused on three factors that we considered to be basic and comparable across countries - level of democracy, per capita income, and education - and that we also expected, on the basis of existing research, to be related to participation and accountability. We also sought to assess the effects of simple budget disclosure, e-participation, and membership in the Open Government Partnership for reasons we discuss below.

\subsubsection{Democracy}

Using contested elections as a measure of democracy and using the missing data in the World Bank dat 3 ase as proxy for government reluctance to disclose information, Rosendorff and Vreeland (2006) found positive relationships between democracy and government transparency. Similarly Rios, Benito, and Bastida (2013) found a relationship between political competition and budget document disclosure. Wehner and De Renzio (2013) have found that countries hosting free and fair elections are more likely to engage in budgetary disclosure, although measures of democratic maturity, which index the extent to which an electorate has substantial experience with budgetary literacy, were not similarly related. Finally, research by Sayogo and Harrison (2013) also found positive significant relationships between a measure of democracy and budget document disclosure.

Since democracy is fundamentally concerned with opening up decision making opportunities to the governed, especially poor and minorities (Halachmi \& Holzer, 2010), one would expect that democracy would be positively associated with participation. However, democracies can vary in the extent to which their citizenries take active roles in the affairs of government decision making (Norris, 2001, p. 217) so we do not expect this relationship to be perfect. Carlitz (2013) found that formal or legal empowerments can help to institutionalize participation and access to budgetary information. This finding is consistent with other research in development contexts that suggests that democratization is significant in understanding the success of transparency and accountability initiatives (McGee \& Gaventa, 2011). Of substantial importance is the pressure for re3 ction, which, as pointed out by Bardhan and Mookherjee (2006), is a mechanism for ensuring the accountability of governments, especially in developing countries. Studies of corruption, the other side of the accountability coin, have found that democracy reduces corruption, but this relationship is tempered by the age of the democracy and the degree of electoral participation, as discussed in Lambsdorff's (2006) review of the literature. Given the weight of this evidence, we predicted:

H1. Democracy is positively related to and significantly influences measures of countries' fiscal transparency, participation, and accountability.

\subsubsection{Gross domestic product per capita (GDP per capita)}

Past research suggests that economic factors affect transparency as one might expect, namely that wealthier countries have more resources, greater technical capacity, and a more positive attitude toward transparency (Bastida \& Benito, 2007; Grigorescu, 2003; Rosendorff \& Vreeland, 2006). Although this relationship has empirical support, additional research has indicated that the effect of income may be complex, interacting with the type of resource and political regime, as countries characterized by greater endowments of or dependency on natural and mineral resources score differentially on transparency depending upon regime type (De Renzio, Gomez, \& Sheppard, 2009; Ross, 2011).

The relationship between economic development or wealth and participation in public affairs is long standing - people who live in countries where the population is economically better off demand more freedoms, including more open government (Bell, 1973; Norris, 2001). However, efforts to link participation with measures of economic development and wealth in developing countries yield results that, while supportive, are more suggestive and vary by country, as indicated generally by Bardhan and Mookherjee (2006) and further supported by their review of several qualitative studies of participatory budgeting. On the other hand, asymmetries in wealth and measures of GDP per head, are consistently related to the incidence of corruption in studies reviewed by Bardhan and Mookherjee (2006) and Lambsdorff (2006), although causality has been difficult to establish. We predicted:

H2. GDP per capita is positively related to and significantly influences measures of countries' fiscal transparency, participation, and accountability.

\subsubsection{Human capital}

There is near universal agreement on the importance of an educated public to achieving the benefits and efficacy of transparency. The public's ability to read and understand budget information is critical to increasing their awareness of fiscal information and becoming less susceptible to fiscal manipulation (De Renzio \& Krafchik, 2010; Rios et al., 2013; Sharma, 2008). Economic development, literacy, and education are mutually interrelated and each facilitates civic participation in established democracies (Norris, 2001). Further, the educational level of the electorate affects the impact of transparency on corruption and the ability of stakeholders to hold government accountable (Kolstad \& Wiig, 2009). The evidence for the effects of education on participation and accountability in less developed countries is, again, more suggestive than absolute (Bardhan \& Mookherjee, 2006; Lambsdorff, 2006), but provides additional support for our prediction:

H3. Human capital is positively related to and significantly influences measures of countries' fiscal transparency, participation, and accountability. 
3.1.4. Budget disclosure

As mentioned earlier, it is important to distinguish between the simple act of disclosing budget documents and the completeness and timeliness of information that is disclosed in those documents; however, we expected that these two approaches to transparency will be related to each other. Disclosure of some kind would seem to be necessary for fiscal participation and accountability (Khagram et al., 2013); at the same time, the mere presence of transparency is, by itself, not sufficient to produce fiscal participation and accountability efforts (McGee \& Gaventa, 2011). As Carlitz (2013) suggests "the act of making budget information available should facilitate greater accountability than would total opacity by allowing the public...to check the information against actual outcomes...." This was amply illustrated in the work of Ferraz and Finan (2008), who reported that dissemination of the findings of an audit in Brazilian cities led to the accountability of politicians seeking reelection in that the higher the level of corruption reported by the audits, the less likely incumbent politicians were to be elected.

In choosing this path, we sought to differentiate the simple act of budget document disclosure from transparency related to information completeness and the temporal conditions under which disclosure takes place. In so doing, we followed the reasoning of Bouten, Everaert, and Roberts (2012) who explored the possibility that the determinants of an organization's voluntary decision to disclose certain social and environmental information may not be identical to the determinants of the level of social and environmental disclosure in which they engage. Analogously, we reasoned that a country's disclosure of particular budget documents may not be identical to the factors that predict which kinds of information those documents contain, whether that information is released on a timely basis, or additional participation and accountability practices that accompany this information. Thus we predicted that:

H4. Budget document disclosure is positively related to and significantly influences measures of fiscal transparency, participation, and accountability.

\subsubsection{E-participation}

E-participation reflects the extent to which a country's electronic government (e-government) capabilities provide a variety of opportunities for public participation, reflecting the hope that ICTs can provide channels that facilitate public engagement. The UN's e-participation measure indexes the extent to which government creates an environment in which citizens can take part in political processes ranging from receiving information electronically to being consulted about opinions to engaging electronically in decision making (Åström et al., 2012). Although the realm of e-government traditionally encompasses far more than fiscal information, we reasoned that more sophisticated e-government capabilities would support the distribution of greater budget information, as well as programs for public participation and accountability processes.

Capacities for information and opinion sharing through the internet have certainly given rise to high expectations about the use of these technologies for facilitating consultation and participation (see, e.g., Coleman, 1999; Halachmi \& Holzer, 2010). Earlier in the history of the internet, Norris (2001) found that measures of e-governance were associated with the use of the web to distribute information to citizens if not, at that time, to engage citizens in two-way dialogue, but acknowledged the potential for doing so as technology diffused. More recently, Bonson, Torres, Royo, and Flores (2012) found that local governments are using web 2.0 and social media tools to improve transparency, but still have much to accomplish in using such tools for promoting dialogue and participation between citizens and government. Further, Williams, Gulati, and Yates (2013) found that a measure of government performance that included indicators of government effectiveness, voice and accountability, and regulatory quality was positively and significantly associated with the UN's E-Participation Index in an extensive international comparison. Thus, we predicted:

H5. E-participation is positively related to and significantly influences measures of countries' fiscal transparency, participation, and accountability.

\subsubsection{OGP commitment}

Membership in the OGP is predicated upon the articulation of commitments by a nation to activities designed to increase transparency, participation, and accountability (http://www.opengovpartnership. org/). Countries wishing to join must initially establish their eligibility, which is accomplished by demonstrating a minimum level of commitment to open government principles in four key areas (Fiscal Transparency, Access to Information, Income and Asset Disclosures, and Citizen Engagement). Following certification of eligibility by independent experts, countries submit a letter of intent and draft an open government action plan. The action plan identifies specific action commitments that will be carried out over a period of two years, and describes how these actions are related to the development of greater transparency, participation, and accountability (see http://www.opengovpartnership.org/ how-it-works/action-plans for further information). The OGP was formally inaugurated in fall, 2011, the point at which many countries would have been in the course of fulfilling these commitments. Although we know of no prior research assessing the impact of OGP participation, we hypothesized:

H6. OGP commitment is positively related to and significantly influences measures of countries' fiscal transparency, participation, and accountability.

\subsection{Measurement of transparency, participation, and accountability}

The Open Budget Survey (OBS) evaluates the budget disclosure practices of the central/national governments of a global sample of countries. The survey is designed to assess the availability in each country of key budget documents, the comprehensiveness of information in each of the budget documents, and related participation and accountability practices (De Renzio \& Masud, 2011; Masud, 2011). The OBS provides information about what happens in practice, rather than what is mandated by law, acknowledging that there is frequently a discrepancy between these two. The OBS is not a perceptual survey in that it does not address perceptions of a general public about the availability and content of budget information. Instead, completion of the surveys is undertaken by independent researchers recruited from each of the respective countries. The researchers are budget experts who are speakers of the national language but unaffiliated with the national government, conditions supporting the validity of the findings by ensuring complete collection of information and limiting subjectivity. Following data collection, two anonymous experts with no government affiliation independently review the results of the survey (International Budget Partnership, 2010).

The Open Budget Index (OBI) is a composite transparency score created by averaging each country's responses to 92 of the 123 questions included in the Survey (Seifert, Carlitz, \& Mondo, 2013). A substantial amount of research has used the $\mathrm{OBI}$ in assessing correlates of national level transparency scores (see e.g., Ross, 2011; Wehner \& De Renzio, 2013). However, as Seifert et al. (2013) point out, the Survey can also be broken down into indexes that reflect the interests of particular research studies. Such has been the case with research that has used items assessing whether particular budget documents are disclosed as a measure of transparency practices (see, e.g., Rios et al., 2013; Sayogo \& Harrison, 2013).

As discussed in the Method section below, rather than using the composite Open Budget Index or simple measures of disclosure, 
we used OBS questions to provide 4 measures of particular types of transparency (budget content, performance information, release of a budget pre-proposal, and timely budget release), two measures of participation (executive participation with the public and the participation of the Supreme Audit Institution with the public) and four measures of accountability (as indicated by information included in four key audit documents) related to the characteristics described above.

\section{Method}

We sought to assess the empirical relationships between the 6 socio-cultural, economic, political, and government factors defined above, as independent variables, and 10 dependent variables in the form of indexes of transparency content and timeliness, participation, and accountability for an international sample of nation-states. The sample consisted of those countries that responded to the 2012 Open Budget Survey; data was collected in the last half of 2011 and released to the public in mid-January 2013. Our analysis used 98 out of 100 countries that responded to 2012 survey with two countries dropped due to missing data, namely: Zimbabwe for human capital index and Sao Tome for democracy index.

All the dependent variables and one of the independent variables (budget document disclosure) were constructed on the basis of data from the 2012 OBS commissioned by the International Budget Partnership. The 2012 OBS differs from prior administrations of the Survey in 2008 and 2010 in a number of respects. The number of observations increased to 100 countries from 94 in 2010 and 85 in 2008. Further, some of the survey items were dropped in favor of including more items assessing budget participation with the public, the legislature, and on the part of the Supreme Audit Institution of each country (International Budget Partnership, 2010; International Budget Partnership, 2011a).

\subsection{Variables description and measurement}

\subsubsection{Dependent variables}

Our dependent variables were indexes that we constructed using items from the 2012 Open Budget Survey (International Budget Partnership, 2011a, 2011b). The OBS is focused on assessing the range and depth of information available to the public about national budgets for countries around the world. The desirability of particular types of information is frequently established by OECD (2002) in a set of best practices that are recommended for budgeting processes. We relied heavily on the categories, and constitutive items within each, that are delineated in the survey. Our dependent variables fell into three domains, as defined below.

Transparency measures consisted of four dependent variables that assessed the kinds of information provided in the Executive's Budget Proposal and Pre-Budget Statement, and timeliness. Specifically, they were:

A Content in the Executive Budget Proposal and Supporting Documents (which we abbreviate as "Content"): This consists of 47 items inquiring about the expenditures, revenues and sources, government debt, macroeconomic assumptions, estimates of the foregoing from prior years, and information about fiscal policies outside central government that bear on future and current budgets.

^ Performance Monitoring (which we abbreviate as "Performance"): A set of 8 items that focuses on the relationships between the budget estimates and policy goals. The answers enable citizens to monitor the outputs and outcomes of the budget.

^ Pre-Budget Statement: In this document the executive aligns policy goals and resources, creating expectations for the forthcoming budget. Best practice requires the executive to release the Statement one month before the budget proposal goes to the legislature. The index of 3 questions focuses on release time and desirable content in the Pre-Budget Statement.

a Timeliness: Three questions assess the extent to which the executive announces in advance and adheres to a publicly available date for releasing the Executive Budget to the legislature and also a publicly announced timetable for internal processes related to the budget preparation process. These timeliness considerations make it possible for the legislature and the public to prepare for budget debates.

Participation dependent variables consisted of two indexes assessing the extent to which the Executive and the Supreme Audit Institution of each country engage the public in budgetary activities for which they are responsible. The two indexes were:

^ Public Participation: This 5-item index assesses practices used by the executive to engage with the public during budget formulation and execution, including legal frameworks consultation mechanisms and ways of soliciting information, and the provision of feedback.

4 SAI Participation: This 3-question index assesses public engagement in audit activities undertaken by the Supreme Audit Institution via solicitation of suggestions for its audit agenda, outreach by the SAI regarding audit findings, and providing information about the audit process.

Accountability dependent variables consisted of four indexes assessing the informational content of 4 kinds of budget reports across various stages of completion; the last index focuses more specifically on the activities of the Supreme Audit Institution.

A In-Year Report Information (which we abbreviate to "in-year report"): Issued during the year a particular budget is implemented and, according to OECD guidelines, should be issued on a monthly basis. The content of the in-year reports covers expenditures, revenues, and borrowing; the level of detail associated with each kind of information; and comparison of actual values with estimates.

A Mid-Year Reports Information (abbreviated to "mid-year report"): Issued six months into the budget year and presents more detail than in-year reports. Covers year-to-date budget performance data.

A Year-End Report Information (abbreviated to "year-end report"): Issued at the end of a budget year, and covers all major items on the budget, with explanations of differences between estimates and outcomes for expenditures, revenues, debt, and macroeconomic assumptions.

A SAI Practices: Comprised of 11 questions focusing on practices of the Supreme Audit Institution and their creation of an audit of final accounts at the end of the budget year. Covers timeliness of the audit report, independence of the SAI itself and investigatory and auditing powers, SAI staffing, and outreach to the legislature and public.

The indexes for each dependent variable were computed in the following way: There were four responses to nearly all the questions, which ranged from the most positive answer "a" reflecting what the Open Budget Partnership (and frequently the OECD) considered the best practice for the subject matter of the question; the next most positive answer "b", reflecting good practice; the next answer "c" reflecting poor/weak practice; and the last answer "d" which was the most negative answer. Survey coders could also provide the answer "e," which designated the question as not applicable. If the question was designated not applicable, it was dropped from the index for that country. Otherwise, following OBS practice, the letters of the answers were translated to numerical values as follows: an "a" response was scored as 100\%; a "b" response was scored as 67\%; a "c" response was scored as 33\%; and a " $\mathrm{d}$ " response was scored 0 . The 
scores for all items in an index were summed and divided by the number of items comprising that index. The formula to calculate this index is:

index $=\sum_{i=0}^{n}\left\{\left(a_{i} * 100 \%\right)+\left(b_{i} * 67 \%\right)+\left(c_{i} * 33 \%\right)+\left(d_{i} * 0 \%\right)\right\} /\left(n-\sum_{i=0}^{n} e_{i}\right)$

Or, for questions giving a response with only three options, the first presented the preferred response, the second represented a negative response, and the third option indicated that the question was not applicable; the score was calculated using the following formula:

index $=\sum_{i=0}^{n}\left\{\left(a_{i} * 100 \%\right)+\left(b_{i} * 0 \%\right)\right\} /\left(n-\sum_{i=0}^{n} c_{i}\right)$.

\subsubsection{Independent variables}

4.1.2.1. Democracy. This variable was based on the annual democracy index survey administered by the Economist Intelligence Unit (EIU) for the year of 2011. The EIU's index of democracy measures the state of democracy in a particular country. This variable is a composite variable constructed from 3 sub-variables of the democracy indicator from EIU, namely: electoral process and pluralism, political participation, and civil liberties. We factor analyzed the items producing one factor with an eigenvalue 2.47; all variables loaded on a single factor at or above 0.5 . The reliability estimates (Cronbach's alphas) for this composite are 0.8714 , indicating a reliable estimate above the rule of thumb of .70 .

4.1.2.2. GDP per capita. GDP per capita was based on data from World Bank for the year 2011 (http://data.worldbank.org/indicator/NY.GDP. PCAP.CD) except for Myanmar. The GDP per capita data for Myanmar for 2011 is not available so we used the predicted GDP per capita for Myanmar based on the economic outlook from the International Monetary Fund (IMF) (http://www.imf.org/external/pubs/ft/weo/2011/02/ weodata/index.aspx). We centered the GDP per capita data by dividing GDP per capita with the mean to reduce the discrepancy in range from that of other variable measurements.

4.1.2.3. Human capital. We used the Human Capital Index from the UN E-Government Readiness survey for the year 2012. The UN Human Capital Index is calculated based on the UNDP (United Nations Development Programme) education index. This variable is a composite of the adult literacy rate and gross school enrollment ratio. The composite is calculated based on weighted standardized score with two-thirds weight assigned to adult literacy and one-third weight assigned to gross enrollment. The gross enrollment is a combination of primary, secondary and tertiary enrollment. For data availability and measurement please refer to http://unpan3.un.org/egovkb/.

4.1.2.4. Budget document disclosure. This measure was based on the availability of six key budget documents to the public, either online or in hard copy. Specifically, as described by De Renzio and Masud (2011), we focused on the following documents:

A Pre-budget Statement: a statement submitted to the legislature presenting the assumptions used in developing the budget, expected revenue and expenditure, debt levels, and broad allocations of budget. This document is generally created and transmitted prior to the submission of the executive budget proposal.

A Executive budget proposal: details budget priorities and policies, target revenue and expenditures, and specific allocations for the upcoming budget year. This document is submitted to the legislature for a review and approval.

^ Citizens budget: a simplified summary of the budget in language for the general public.

A Mid-year review: presents changes in the economic assumptions affecting the enacted budget.
A Year-end review: summarizes and reports budget data at the end of the fiscal year incorporating any changes made during the fiscal year.

A Audit report: independent auditors' report regarding verifiability of budget implementation.

To construct this variable, we used a simple count of the number of these documents that were publicly available (noting that some information may not be present in the document). The International Budget Partnership uses three units of measurement, a) available to the public, b) available for internal use only, and c) not produced. If the budget document is available to the public or for internal use, we assigned a value of 1 and if it is not produced we assigned a value of 0 . The value of this variable is a summation of the number of budget documents available across the six types to arrive at a measure of budget document disclosure.

4.1.2.5. E-participation. We used the scores from the E-Participation Index from the UN E-Government Readiness survey for the year 2012. The UN's E-Participation Index is created from questions that focus on: a) e-information sharing which is a provision of information from government to citizens, b) e-consultation refers to interaction of government with stakeholders, and c) e-decision making, which assesses engagement of citizens in decision-making processes. As discussed in the E-Government Readiness report, the E-Participation Index is a normalized composite of scores for all three dimensions. Information about data and measurement can be obtained from the Methodology Section of the UN e-Government Readiness report in the appendices of the document ${ }^{2}$.

4.1.2.6. OGP commitment. We measured this variable using an ordinal scale based on commitments of OGP's participating countries for plans to enhance transparency, participation, and accountability. There are three levels of involvement: a) countries who have delivered their commitment, b) countries developing their commitment and c) countries not yet participating in OGP. Using OGP membership as of late 2011, a value of 2 is assigned to countries that have already delivered their commitments to OGP, a value of 1 for countries developing their commitment to OGP, and a value of 0 for those who are not yet participating in the OGP.

\section{Data analysis and results}

1

We used hie 1 chical ordinary least squares (OLS) regression to test our hypotheses. Hierarchical OLS allows us to enter va 1 ables in a series of blocks with the results at each step indicating the relative influence of the variables on the dependent variable, while controlling for the influence of variables entered at prior steps. We also took all the necessary steps to satisfy the Gauss-Markov conditions for our regression analysis ${ }^{3}$.

In order to examine the multiple effects of the national level conditions, we began by entering democracy, GDP, and human capital as a block during the first stage of analysis, which we designated as Model 1. Model 1 has the following form.

$Y_{n}=a+\beta_{1} G D P+\beta_{2}$ Democracy $+\beta_{3}$ HumanCapital $+\in$,

where $Y_{n}$ represents each individual dependent variable ( 4 transparency variables, 2 participation variables, and 4 accountability variables).

\footnotetext{
2 http://unpan1.un.org/intradoc/groups/public/documents/un/unpan048065.pdf.

${ }^{3}$ We ran an ovtest to test for possible endogeneity caused by omitted variable bias and found no endogeneity in the model. We also minimized the possible endogeneity caused by measurement errors since our variable selection and measurement are based on preexisting and tested variables. Our model and variable selections are also based on rigorous review of literature to avoid possible simultaneity issues. We also ran the regression using Huber/White estimator to resolve the possible issue of heterogeneity (see Torres-
} Reyna, 2007. Linear Regression Using Stata, v.6.3, Statistical Handout). 
Following that, we entered the variable indexing budget document disclosure. At the next step, we entered our measure of e-participation, and finally we entered the indicator of OGP commitment; we designated the combined results of these 3 three steps as Model 2. Model 2 has the following form.

$$
\begin{aligned}
Y_{n}= & a+\beta_{1} G D P+\beta_{2} \text { Democ }+\beta_{3} \text { HumanCap }+\beta_{4} \text { BgtDisclosure } \\
& +\beta_{5} \text { ePart }+\beta_{6} \text { OGP }+\in
\end{aligned}
$$

Comparing the two models enables us to determine whether, controlling for democracy, GDP, and human capital, the additional variables of budget document disclosure, e-participation, and OGP membership contributed additional variation to the explanation of transparency, participation and accountability.

The unstandardized regression coefficients for each model are presented in Table 2 for the transparency dependent variables, Table 3 for the participation dependent variables, and Table 4 for the accountability dependent variables. Each of the models was significant at $p \leq .05$ or better; below we discuss the predictors that were significant within each model and the amount of variance accounted for by each model. The amount of variance is reflected in the adjusted $R^{2}$ value of each model. Table 1 presents a compilation of the results by independent variable, which enables us to more easily view how each of these factors performed with respect to each dependent variable and to assess the outcomes of our hypotheses.

\subsection{Democracy}

Democracy emerged as a significant and positive predictor of transparency content, performance, pre-budget statement, and timeliness; however, for the latter two variables, democracy lost significance in Model 2. Democracy was also a significant and positive predictor of participation in Model 1 for both public participation and SAI participation. Finally, democracy significantly and positively predicted all four types of accountability, but dropped out of Model 2 for in-year report and for end-year report. Given that democracy was a significant and positive predictor in 14 of the 20 regressions, we conclude that there is substantial support for $\mathrm{H} 1$.

\subsection{GDP}

In contrast, gross domestic product per capita emerged as a significant predictor in a small number of the regressions, and its contribution was always negative. GDP was a significant but negative predictor of performance and pre-budget statements, but only in Model 2 for each. GDP was also significant and negative in predicting timeliness for each of the two models. GDP was not significantly related to either Public or SAI participation. For the accountability dependent variables, GDP was a significant and negative predictor of in-year report and SAI practices, but again only in Model 2 for each. Thus it appears that GDP was negatively related to timely notification of the budget no matter what else was in the model, but with respect to performance, pre-budget statement, in-year report and SAI practices, GDP was only significant in Model 2. Thus we find no support for $\mathrm{H} 2$; in fact, our results directly contradict our expectations.

\subsection{Human capital}

Human capital was a significant predictor for three of the four transparency variables, one of the participation variables, and three of the four accountability variables. Its contribution was always positive. For performance (transparency), human capital was significant for both models; for SAI participation, it was similarly significant for both models. However, for content and timeliness (transparency variables) and in-year reports, year-end reports, and SAI practices (accountability), human capital was significant only in each Model 1. Human capital was not related to pre-budget statements, public participation, or midyear reports. We thus found consistent but not uniform support for $\mathrm{H} 3$; it appears to be especially important for performance information and SAI participation. In every other second model, the influence of human capital failed to make a significant contribution to the equation.

As indicated earlier, Model 1 served as a control for the effects of democracy, GDP, and human capital; in computing Model 2 for each variable, we sought to understand the independent effects of budget document disclosure, e-participation, and OGP membership.

\subsection{Budget document disclosure}

For the four transparency practices, budget document disclosure was a significant and positive predictor; it was a significant and positive predictor for 3 of the 4 accountability variables (mid-year reporting, end-year reporting, and SAI reporting). Budget document disclosure did not predict either form of participation. We thus find substantial support for $\mathrm{H} 4$, but only for the transparency and accountability variables.

Table 1

\begin{tabular}{|c|c|c|c|c|c|c|c|}
\hline Dependent/independent & & GDP & Democracy & Human capital & Budget disclosure & E-par & OGP \\
\hline \multirow[t]{2}{*}{ Content } & Model 1 & - & Sig/Pos & Sig/Pos & $n / a$ & $n / a$ & $n / a$ \\
\hline & Model 2 & - & Sig/Pos & - & Sig/Pos & - & Sig/Pos \\
\hline \multirow[t]{2}{*}{ Performance monitoring } & Model 1 & - & Sig/Pos & $\mathrm{Sig} / \mathrm{Pos}$ & $n / a$ & $n / a$ & $n / a$ \\
\hline & Model 2 & $\mathrm{Sig} / \mathrm{Neg}$ & $\mathrm{Sig} / \mathrm{Pos}$ & Sig/Pos & $\mathrm{Sig} / \mathrm{Pos}$ & - & - \\
\hline \multirow[t]{2}{*}{ Pre-budget } & Model 1 & - & $\mathrm{Sig} / \mathrm{Pos}$ & - & $n / a$ & $n / a$ & $n / a$ \\
\hline & Model 2 & $\mathrm{Sig} / \mathrm{Neg}$ & - & - & $\mathrm{Sig} / \mathrm{Pos}$ & $\mathrm{Sig} / \mathrm{Pos}$ & - \\
\hline \multirow[t]{2}{*}{ Timeliness } & Model 1 & $\mathrm{Sig} / \mathrm{Neg}$ & $\mathrm{Sig} / \mathrm{Pos}$ & $\mathrm{Sig} / \mathrm{Pos}$ & $n / a$ & $n / a$ & $n / a$ \\
\hline & Model 2 & Sig/Neg & - & - & Sig/Pos & $\mathrm{Sig} / \mathrm{Pos}$ & - \\
\hline \multirow[t]{2}{*}{ Public participation } & Model 1 & - & $\mathrm{Sig} / \mathrm{Pos}$ & - & $n / a$ & $n / a$ & $n / a$ \\
\hline & Model 2 & - & - & - & - & - & - \\
\hline \multirow[t]{2}{*}{ SAl participation } & Model 1 & - & Sig/Pos & $\mathrm{Sig} / \mathrm{Pos}$ & $n / a$ & $n / a$ & $n / a$ \\
\hline & Model 2 & - & - & Sig/Pos & - & - & Sig/Pos \\
\hline \multirow[t]{2}{*}{ In-year report } & Model 1 & - & $\mathrm{Sig} / \mathrm{Pos}$ & Sig/Pos & $n / a$ & $n / a$ & $n / a$ \\
\hline & Model 2 & $\mathrm{Sig} / \mathrm{Neg}$ & - & - & - & $\mathrm{Sig} / \mathrm{Pos}$ & Sig/Pos \\
\hline \multirow[t]{2}{*}{ Mid-year report } & Model 1 & - & $\mathrm{Sig} / \mathrm{Pos}$ & - & $n / a$ & $n / a$ & $n / a$ \\
\hline & Model 2 & - & Sig/Pos & - & $\mathrm{Sig} / \mathrm{Pos}$ & - & - \\
\hline \multirow[t]{2}{*}{ Year-end report } & Model 1 & - & Sig/Pos & $\mathrm{Sig} / \mathrm{Pos}$ & $n / a$ & $n / a$ & $n / a$ \\
\hline & Model 2 & - & - & - & $\mathrm{Sig} / \mathrm{Pos}$ & $\mathrm{Sig} / \mathrm{Pos}$ & - \\
\hline \multirow[t]{2}{*}{ SAI practices } & Model 1 & - & $\operatorname{Sig} /$ Pos & Sig/Pos & $n / a$ & $n / a$ & $n / a$ \\
\hline & Model 2 & $\mathrm{Sig} / \mathrm{Neg}$ & Sig/Pos & - & Sig/Pos & $\mathrm{Sig} / \mathrm{Pos}$ & - \\
\hline
\end{tabular}

Summary of the results. 
Table 2

Regression results for transparency.

\begin{tabular}{|c|c|c|c|c|c|c|c|c|c|}
\hline \multirow[t]{2}{*}{ Variable } & & \multicolumn{2}{|l|}{ Content } & \multicolumn{2}{|c|}{ Performance monitoring } & \multicolumn{2}{|l|}{ Pre-budget } & \multicolumn{2}{|l|}{ Timeliness } \\
\hline & & Model 1 & Model 2 & Model 1 & Model 2 & Model 1 & Model 2 & Model 1 & Model 2 \\
\hline \multirow[t]{3}{*}{ GDP } & coeff & -1.21 & -1.78 & -4.74 & -6.90 & -1.68 & -12.14 & -8.72 & -13.26 \\
\hline & se & 1.88 & 2.43 & 2.63 & 3.39 & 4.06 & 3.93 & 3.25 & 3.80 \\
\hline & $p$ & .523 & .467 & .075 & .045 & .680 & .003 & .009 & .001 \\
\hline \multirow{3}{*}{ Democracy } & coeff & 10.87 & 9.68 & 9.32 & 8.36 & 5.38 & 2.47 & 5.61 & 3.69 \\
\hline & se & 1.33 & 1.45 & 1.48 & 1.72 & 2.70 & 2.27 & 2.35 & 2.41 \\
\hline & $p$ & .000 & .000 & .000 & .000 & .049 & .279 & .019 & .129 \\
\hline \multirow[t]{3}{*}{ Human capital } & coeff & 26.46 & 14.32 & 54.97 & 40.44 & 37.67 & -18.53 & 67.54 & 36.53 \\
\hline & se & 12.13 & 13.17 & 16.08 & 17.55 & 29.86 & 28.76 & 22.58 & 22.90 \\
\hline & $p$ & .032 & .280 & .001 & .023 & .210 & .521 & .004 & .114 \\
\hline \multirow[t]{3}{*}{ Budget document disclosure } & coeff & & 3.39 & & 6.01 & & 18.30 & & 4.79 \\
\hline & se & & 1.66 & & 2.57 & & 2.83 & & 2.40 \\
\hline & $p$ & & .044 & & .022 & & .000 & & .049 \\
\hline \multirow[t]{3}{*}{ E-participation } & coeff & & 6.88 & & 20.88 & & 107.99 & & 53.36 \\
\hline & se & & 17.70 & & 20.40 & & 34.70 & & 26.82 \\
\hline & $p$ & & .698 & & .309 & & .002 & & .050 \\
\hline \multirow[t]{3}{*}{ OGP commitment } & coeff & & 7.06 & & 2.51 & & 2.37 & & 6.82 \\
\hline & se & & 2.74 & & 4.14 & & 6.08 & & 5.15 \\
\hline & $p$ & & .012 & & .545 & & .697 & & .189 \\
\hline \multirow[t]{3}{*}{ Constant } & coeff & 46.49 & 37.21 & 48.89 & 40.71 & 33.21 & 35.94 & 105.36 & 118.76 \\
\hline & se & 14.05 & 18.58 & 18.77 & 21.85 & 27.16 & 29.78 & 22.57 & 27.07 \\
\hline & $p$ & .001 & .048 & .011 & .066 & .224 & .231 & .000 & .000 \\
\hline $\mathrm{N}$ & 98 & 98 & 98 & 98 & 98 & 98 & 98 & 98 & \\
\hline$F$ & $67.66^{\circ * *}$ & $43.25^{\circ}$ & $32.33^{* * *}$ & $23.48^{* * *}$ & $4.03^{\circ *}$ & $18.08^{* * *}$ & $9.16^{* * *}$ & $5.58^{* * *}$ & \\
\hline Adjusted $R^{2}$ & .50 & .54 & .39 & .44 & .07 & .40 & .15 & .21 & \\
\hline
\end{tabular}

Note: $1 \leq .05, " * p \leq .01,{ }^{* * *} p \leq .001$.

Note: Bold emphasis indicates values that are statistically significant at the p level indicated.

\subsection{E-participation}

E-participation emerged as a significant and positive predictor of pre-budget statement and timeliness (two of the transparency practices) and three of the four accountability variables (in-year reports, year-end reports, and SAI practices). Interestingly, for each dependent variable except SAI practices, whenever e-participation enters the equation as significant, democracy and/or human capital, which

Table 3

Regression results for participation.

\begin{tabular}{|c|c|c|c|c|c|}
\hline \multirow[t]{2}{*}{ Variable } & & \multicolumn{2}{|c|}{ Public participation } & \multicolumn{2}{|c|}{ SAl participation } \\
\hline & & Model 1 & Model 2 & Model 1 & Model 2 \\
\hline \multirow[t]{3}{*}{ GDP } & coeff & -2.39 & -4.25 & -.22 & -1.37 \\
\hline & se & 1.87 & 2.52 & 2.45 & 2.45 \\
\hline & $p$ & .204 & .095 & .93 & .58 \\
\hline \multirow[t]{3}{*}{ Democracy } & coeff & 2.38 & 1.60 & 3.50 & 2.1 \\
\hline & se & 1.14 & 1.17 & 1.72 & 1.71 \\
\hline & $p$ & .041 & .176 & .04 & .223 \\
\hline \multirow[t]{3}{*}{ Human capital } & coeff & 25.70 & 13.15 & 65.70 & 49.64 \\
\hline & se & 16.13 & 14.63 & 18.25 & 23.52 \\
\hline & $p$ & .114 & .371 & .001 & .038 \\
\hline \multirow{3}{*}{$\begin{array}{l}\text { Budget document } \\
\text { disclosure }\end{array}$} & coeff & & 2.10 & & 2.56 \\
\hline & se & & 1.75 & & 1.77 \\
\hline & $p$ & & .233 & & .151 \\
\hline \multirow[t]{3}{*}{ E-participation } & coeff & & 21.60 & & 15.33 \\
\hline & se & & 18.73 & & 25.40 \\
\hline & $p$ & & .252 & & .55 \\
\hline \multirow[t]{3}{*}{ OGP commitment } & coeff & & 2.67 & & 8.13 \\
\hline & se & & 4.40 & & 3.96 \\
\hline & $p$ & & .55 & & .043 \\
\hline \multirow[t]{3}{*}{ Constant } & coeff & 22.62 & 27.53 & -8.17 & -10.15 \\
\hline & se & 11.62 & 18.38 & 15.07 & 17.85 \\
\hline & $p$ & .055 & .138 & .59 & .57 \\
\hline $\mathrm{N}$ & & 98 & 98 & 98 & 98 \\
\hline$F$ & & $2.91^{\circ}$ & $2.36^{\circ}$ & $21.23^{* * *}$ & $16.68^{* * *}$ \\
\hline Adjusted $R^{2}$ & & .08 & .09 & .37 & .40 \\
\hline
\end{tabular}

Note: $1 \leq .05, " p \leq .01, " * p \leq .001$.

Note: Bold emphasis indicates values that are statistically significant at the p level indicated. had been significant in Model 1, lose their significance. Thus it appears that e-participation encompasses the variation contributed by democracy and human capital, and provides additional explanatory power. Interestingly, the measure of e-participation did not predict either form of public participation. Thus, we find limited support for H5: e-participation clearly plays an important role in predicting certain transparency and accountability variables, but not in predicting participation.

\subsection{OGP membership}

OGP membership emerged as a significant and positive predictor of transparency content, SAI participation, and in-year reports. This variable did not contribute to the variance explained for any other dependent variable. We thus concluded that $\mathrm{H} 6$ had quite limited support; however, interestingly it did contribute to the equation for one practice in each of the transparency, participation, and accountability sets.

Another informative way to explore these results is to look at the regressions from the perspective of the variance accounted for in each of the dependent variables.

\subsection{Transparency}

Table 2 presents the significant predictors and variance accounted for in each model describing budget content, performance, pre-budget statement, and timeliness. For content transparency, Model 1 accounted for $50 \%$ of the variance, with democracy and human capital as statistically significant predictors. In Model 2, human capital lost significance, but budget document disclosure and OGP commitment entered as significant predictors, increasing the percentage of explained variance to $54 \%$.

In the analysis of performance transparency, democracy and human capital were again significant predictors in Model 1, which accounted for $39 \%$ of the variance. For Model 2, GDP entered the equation as a significant negative predictor $(\beta=-6.90, p \leq .05)$ and budget document disclosure as a significant positive predictor $(\beta=6.01, p \leq .05)$, raising the level of explained variance to $44 \%$.

For pre-budget statement, democracy was the only significant predictor in Model 1 accounting for $7 \%$ of the variance. In Model 2, democracy ceased to be significant, but GDP entered as a significant 
Table 4

Regression results for accountability.

\begin{tabular}{|c|c|c|c|c|c|c|c|c|c|}
\hline \multirow[t]{2}{*}{ Variable } & & \multicolumn{2}{|c|}{ In-year reports } & \multicolumn{2}{|c|}{ Mid-year reports } & \multicolumn{2}{|c|}{ End-year reports } & \multicolumn{2}{|c|}{ SAl practices } \\
\hline & & Model 1 & Model 2 & Model 1 & Model 2 & Model 1 & Model 2 & Model 1 & Model 2 \\
\hline \multirow[t]{3}{*}{ GDP } & coeff & -5.60 & -10.47 & -.34 & -1.10 & 1.97 & 4.13 & -1.97 & -6.41 \\
\hline & se & 3.27 & 4.57 & 3.06 & 3.52 & 2.41 & 2.91 & 1.71 & 2.02 \\
\hline & $p$ & .090 & .024 & .912 & .76 & .416 & .160 & .251 & .002 \\
\hline \multirow[t]{3}{*}{ Democracy } & coeff & 7.00 & 4.67 & 8.40 & 7.48 & 4.42 & 2.99 & 6.92 & 5.42 \\
\hline & se & 2.62 & 2.65 & 1.77 & 2.07 & 2.09 & 1.62 & 1.32 & 1.14 \\
\hline & $p$ & .009 & .082 & .000 & .000 & .037 & .067 & .000 & .000 \\
\hline \multirow[t]{3}{*}{ Human capital } & coeff & 63.84 & 27.32 & 8.29 & -1.13 & 45.72 & 15.11 & 49.80 & 22.73 \\
\hline & se & 27.12 & 26.97 & 22.94 & 24.57 & 16.38 & 14.29 & 10.60 & 11.94 \\
\hline & $p$ & .021 & .314 & .719 & .963 & .006 & .293 & .000 & .060 \\
\hline \multirow[t]{3}{*}{ Budget document disclosure } & coeff & & .178 & & 8.46 & & 8.74 & & 3.27 \\
\hline & se & & 3.04 & & 2.60 & & 1.64 & & 1.31 \\
\hline & $p$ & & .953 & & .002 & & .000 & & .014 \\
\hline \multirow[t]{3}{*}{ E-participation } & coeff & & 64.44 & & 1.63 & & 64.29 & & 52.43 \\
\hline & se & & 32.60 & & 29.40 & & 19.57 & & 16.03 \\
\hline & $p$ & & .051 & & .956 & & .001 & & .002 \\
\hline \multirow[t]{3}{*}{ OGP commitment } & coeff & & 10.67 & & 3.42 & & -.05 & & 4.28 \\
\hline & se & & 5.31 & & 6.45 & & 3.62 & & 2.53 \\
\hline & $p$ & & .047 & & .598 & & .988 & & .094 \\
\hline \multirow[t]{3}{*}{ Constant } & coeff & 74.42 & 108.07 & 16.38 & -11.31 & -6.77 & 2.33 & 45.91 & 64.51 \\
\hline & se & 20.63 & 30.54 & 19.72 & 27.14 & 17.12 & 20.48 & 12.08 & 15.85 \\
\hline & $p$ & .000 & .001 & .408 & .678 & .693 & .910 & .000 & .000 \\
\hline $\mathrm{N}$ & & 98 & 98 & 98 & 98 & 98 & 98 & 98 & 98 \\
\hline$F$ & & $11.36^{* * *}$ & $6.08^{* * *}$ & $9.42^{* *}$ & $6.55^{* * *}$ & $22 . .67^{* * *}$ & $26.85^{* * *}$ & $69.77^{* * *}$ & $47.83^{* *}$ \\
\hline Adjusted $R^{2}$ & & .20 & .24 & .17 & .25 & .37 & .56 & .55 & .64 \\
\hline
\end{tabular}

Note: $1 \leq .05, "{ }^{* *} p \leq .01,{ }^{* * *} p \leq .001$.

Note: Bold emphasis indicates values that are statistically significant at the p level indicated.

negative predictor $(\beta=-12.14, p \leq .01)$; budget document disclosure and e-participation also entered the model with significant positive coefficients, increasing the explained variance to $40 \%$.

Finally, for the timeliness model, democracy, human capital, and GDP (again as a negative predictor $\beta=-8.72, p \leq .01$ ) were significant predictors in Model 1, explaining 15\% of the variance. In Model 2, only GDP continued to be negative and significant. However, budget document disclosure entered the equation as a significant predictor $(\beta=4.79, p \leq .05)$ as did e-participation $(\beta=53.36, p \leq .05)$ producing a model that accounted for $21 \%$ of the variance. Thus for both the pre-budget statement and timeliness, budget document disclosure and e-participation contributed significantly to the equations, but only for countries with low GDP per capita.

\subsection{Participation}

Table 3 presents the results related to two forms of participation in fiscal activities. For public participation, democracy was the only significant predictor accounting for $8 \%$ of the variance in Model 1. In Model 2, there are no significant predictors, although the equation was significant. In contrast, the models produced for SAI participation (that is, participation activities managed by the Supreme Audit Authority), accounted for, respectively $37 \%$ and $40 \%$ of the variance. While democracy and human capital are significant in the first model, democracy drops out in Model 2 and is replaced by OGP membership.

\subsection{Accountability}

Table 4 presents the results for the four dependent accountability indexes, each of which consisted of types of report/audit content for the intervals in which a particular kind of fiscal report is created.

For in-year reports, issued on a monthly basis, democracy and human capital emerged as significant predictors in Model 1, which accounted for $20 \%$ of the variance. In Model 2, democracy and human capital dropped out, GDP entered the equation as a significant negative predictor $(\beta=$ $-10.47, p \leq .05)$, along with e-participation $(\beta=64.44, p \leq .05)$ and OGP commitment $(\beta=10.67, p \leq .05)$. Again, it appears that e-participation enters the equation when GDP becomes significant and negative; in this case OGP also contributes significantly to the total explained variance of $24 \%$.

For mid-year report, only democracy was a significant predictor in Model 1, which accounted for $17 \%$ of the variance. Democracy continued to be significant in Model 2, however budget document disclosure was also significant and increased the explained variance to $25 \%$.

For end-year report, democracy and human capital entered Model 1 as significant predictors, accounting for $37 \%$ of the variance. However, in Model 2, they both lost significance, but budget document disclosure and e-participation entered the model as significant predictors accounting for $56 \%$ of the variance.

For SAI practices, both democracy and human capital were significant predictors in Model 1, accounting for $55 \%$ of the variance. In Model 2, GDP became significant as a negative predictor $(\beta=-6.41$, $p \leq .01$ ), democracy continued to be significant, and budget document disclosure and e-participation also entered the equation as significant predictors producing an equation explaining $64 \%$ of the variance.

\section{Discussion}

Our hypotheses were motivated by an interest in evaluating the relationships between socio-cultural, economic, political, and government factors that we expected to be predictive of four types of transparency; two types of participation; and four types of accountability information. It is clear that the predictors that emerged as significant within each of the models generated for the 10 dependent variables differ from each other, along with the percentage of explained variance. Although transparency, participation, and accountability are conceptually interdependent in the context of open government, our data suggests that they are predicted by different combinations of national level conditions.

\subsection{Effects of socio-cultural, political, economic, and government variables}

On the basis of these analyses, it is possible to draw some general conclusions about the independent variables that we considered in model development. It is worth noting that democracy emerged as a statistically significant predictive variable for all the dependent 
variables, thus underscoring the conclusion that a nation's level of democratic development is in fact the most consistent predictor of transparency, participation, and accountability. However, democracy tended to lose significance in Model 2 equations when e-participation was a significant factor, which was the case for analyses that focused on prebudget statement, timeliness, in-year reports, and end-year reports. Because each of these dependent variables is focused to some degree on the issue of providing information that has a time-oriented dimension, we are persuaded that e-participation provides important capabilities that enable the provision of this information. Surprisingly, this is apparently not the case with public participation, since e-participation was not a significant predictor.

Similarly, human capital emerged as a significant predictor in Model 1 for three of the four transparency variables, SAI participation, and three of the four accountability variables. Like democracy, it tended to lose significance when other variables such as e-participation, budget document disclosure, or OGP commitment entered Model 2 as significant variables, suggesting that its variance is subsumed by these predictors. Interestingly, it retained its significance in predicting SAI participation, even though OGP commitment was also a significant component of Model 2, suggesting that a strong Supreme Audit Institution continues to be predicted by having an educated citizenry, beyond what is predicted by OGP commitment.

It is interesting to note that OGP commitment significantly predicts content transparency, SAI participation, and the in-year reports, even given the relative youth of this international initiative; it remains to be seen if further effects will become apparent as the initiative continues to develop. Of course, it is impossible from this data to determine whether this reflects progress in achieving OGP commitments, or if greater content, SAI participation, and in-year reporting characterize countries that meet eligibility requirements. The effects of OGP commitment on these processes will no doubt be of considerable interest in the future.

Budget document disclosure contributed to the explained variation for each of the four transparency measures and three of the four accountability measures, demonstrating that the simple availability of budget documents, regardless of the extent of its substantive content, does have impact. However, disclosure never appeared alone as a significant predictor for any of the dependent measures, suggesting that it may be necessary, but not sufficient. Simple document disclosure cannot be equated with the particular kinds of transparency and accountability, and must therefore be viewed cautiously as an operationalization of transparency in future studies.

Although we expected that GDP would be positively associated with our dependent measures of transparency, participation and accountability, this expectation was not realized. Instead, when GDP contributed significantly to an equation, its contribution was always negative. It is interesting to note that GDP did not emerge as significant in any of the first models, except for the timeliness measure of transparency (and for which it remained significant in Model 2). However, GDP became significant in Model 2 for performance, pre-budget, in-year reports, and SAI practices when budget document disclosure, e-participation, and/or OGP commitment also entered the equations as significant predictors. This would seem to imply that the presence of these factors is negatively related to GDP, suggesting that they characterize countries with lower GDP. This finding may well be explained by Ross's (2011) efforts to distinguish between sources of wealth as it is related to transparency. His research found that, among autocracies, a country's oil wealth is correlated with less transparency. Similarly, De Renzio et al. (2009) found that resource dependency more generally was related to decreases in transparency. Unfortunately, our measure of GDP per capita was not a fine enough gauge to allow us to explore the effects of different sources of wealth. However, our analyses show that the relationship between income, transparency, and accountability is clearly complex and warrants more detailed examination.

\subsection{Transparency, participation, and accountability}

Each of the dependent transparency, participation, and accountability variables presents a different matrix of predictors in models that account for quite different levels of variation. As one might expect, the extent of democracy and human capital each began as significant predictors in Model 1 for most of the transparency and the accountability variables. Beyond this, budget document disclosure was a significant predictor for all the transparency and three of the four accountability variables. The combination of budget disclosure and e-participation appears to be quite powerful. In equations where the two are simultaneously significant, the growth in explained variance over Model 1 is $+33 \%$ for pre-budget statement, $+6 \%$ for timeliness, $+19 \%$ for endyear reports, and $+9 \%$ for SAI practices. The latter model for SAI practices, explains $64 \%$ of the variance, the highest of all the models examined.

Thus, there is some overlap in the patterns of relationships for both transparency and accountability practices. However, there is very little resemblance between these patterns and the predictors of public participation. Only democracy predicts public participation, and even that becomes non-significant in Model 2. A mere $9 \%$ of the variance is explained, far less than that explained by any other model in this research. SAI participation, which references public engagement via solicitations by the Supreme Audit Institution, behaves somewhat differently, with human capital and OGP commitment emerging as significant predictors. It seems plausible to conclude that in countries with high levels of education and an existing OGP commitment, the SAI is able to promote participation in audit activities. This SAI pattern bears some similarity to the patterns produced for transparency and accountability. However, it seems very clear that we have a lot more to learn about the national conditions that are related to public participation in budgeting activities.

\subsection{Limitations}

These findings must be judged in the context of a number of limitations of our design and analytical methods. First, while the data produced by the Open Budget Partnership is of high quality, it is limited to the number of countries that participate in the Open Budget Survey, which for 2012 reached a high of 100 . Of course, the survey data, which was collected in 2011, always lags temporally behind more recent and related events, which are frequent in the dynamic development of open government, and especially in the growth of the Open Government Partnership. We look forward to continued administrations of the Open Budget Survey in coming years.

Second, we need to emphasize that our data is correlational, not causal, which means that the direction of relationships cannot be inferred, no matter how tempting. This is particularly important to recognize when thinking, for example, about the possible effects of e-participation.

Third, since we have made impressionistic comparisons between patterns produced in the regression models and the amount of variance explained, we urge caution in interpreting these differences. We believe a national comparative study such as ours illustrates the effects of socio-cultural, political, economic, and governmental factors on transparency, participation, and accountability in a way that underscores the importance of general macro-level forces. However, we are also cognizant of the fact that histories, demographic characteristics, traditions, and government experiences in using ICTs play out in somewhat unique ways for countries that are democratizing and moving toward open government, which only case studies can illuminate for us.

\section{Acknowledgments}

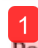

Portions of this manuscript appeared in a conference paper entitled "Open budgets and open government: Beyond disclosure in pursuit of 
transparency, participation and accountability" which was published in dg.o 13, Proceedings of the 14th Annual Digital Government Research Conference. ACM. We are grateful to three anonymous reviewers for their help in making substantial improvements in this manuscript.

\section{References}

Alves, J. A., \& Heller, P. (2013). Accountability from the top down: Brazil's advances in budget transparency despite a lack of popular mobilization. In S. Khagram, A. Fung \& P. DeRenzio (Eds.), Open budgets: the political economy of transparency, participation, and accountability (pp. 76-104). Washington: Brookings Institution Press.

Arnstein. S. R. (1969). A ladder of citizen participation. Joumal of the American Institute of Planners, 35(4), 216-224.

Åström, J., Karlsson, M., Linde, J., \& Pirannejad, A. (2012). Understanding the rise of e-participation in non-democracies: domestic and international factors. Government Information Quarterly, 29(2), 142-150.

Bannister, F., \& Connolly, R. (2011). The trouble with transparency: a critical review of openness e-Government. Policy \& Intermet, 3(1), 158-187.

Bardhan, P.. \& Mookherjee, D. (2006). Decentralization, corruption and government accountability. In S. Rose-Ackerman (Ed.), International handbook on the economic of corruption (pp. 161-188). Cheltenham, UK: Edward Elgar.

Bastida, F., \& Benito, B. (2007). Central government budget practices and transparency: an international comparison. Public Administration, 85(3), 667-716.

Bell, D. (1973). The coming post-industrial society. New York: Basic Books.

Benito, B., \& Bastida, F. (2009). Budget transparency, fiscal performance, and political turnout: an international approach. Public Administration Review, 69(3). 403-417.

Bertot, J. C. Jaeger, P. T., \& Grimes, J. M. (2010). Using ICTs to create a culture of transparency: e-government and social media as openness and anti-corruption tools for societies. Government Information Quarterly, 27, 264-271.

Bimber, B. (2003). Information and American democracy: technology in the evolution of political power. Cambridge: Cambridge University Press.

Birkinshaw, P. (2006). Transparency as a human right. In C. Hood, \& D. Heald (Eds.). Transparency: the key to better governance. Proceedings of the British Academy. (pp. 47-57). Oxford: Oxford University Press.

Bonson, E., Torres, L., Royo, S., \& Flores, F. (2012). Local e-government 2.0: social media and corporate transparency in municipalities. Government Information Quarterly, 29 123-132.

Bouten, L. Everaert, P., \& Roberts, R. W. (2012). How a two-step approach discloses different determinants of voluntary social and environmental reporting. Joumal of Business Finance \& Accounting, 39(5-6), 567-605.

Bowie, N. (1990). Equity and access to information technology. The annual reviews-1990. Queenstown, MD: Institute for Information Studies, 131-177.

Carlitz, R. (2013). Improving transparency and accountability in the budget process: an assessment of recent initiatives. Development Policy Review, 31(s1), S49-S67.

Coleman, S. (1999). Cutting out the middle person. In B. N. Hague, \& B. D. Loader (Eds.), Digital democracy: discourse and decision making in the information age (pp. 195-210). London: Routledge.

Curtis, D., \& Meier, A. J. (2006). Does transparency strengthen legitimacy? Information Polity, 11(2), 109-122.

Dawes, S. (2010). Stewardship and usefulness: policy principles for information-based transparency. Government Information Quarterly, 27, 377-383.

De Renzio, P. Gomez, P. P., \& Sheppard, J. (2009). Budget transparency and development resource-dependent countries. International Social Science Journal, 57(Supplement S1), 57-69.

De Renzio, P., \& Krafchik, W. (2010). Can civil society have an impact? Capacity.org, 31. (pp. 7), 7 (http://lencd.com/data/docs/57-Accountability.pdf. Accessed: Octobe 29, 2013).

De Renzio, P., \& Masud, H. (2011). Measuring and promoting budget transparency: the Open Budget Index as a research and advocacy tool. Governance, 24(3). 607-616.

Dervin, B. (1994). Information-democracy: an examination of underlying assumptions. Journal of the American Society for Information Science, 45(6). 369-385.

Ferraz, C., \& Finan, F. (2008). Exposing corrupt politicians: the effects of Brazil's publicly released audits on electoral outcomes. The Quarterly Journal of Economics, 123(2), 703-745

First Global Assembly for Budget Transparency. Accountability and Participation (2012). The Dar es Salaam Declaration on Budget Transparency, Accountability and Participation | Make Budgets Public: 2012. http://www.makebudgetspublic.org/the-dar-essalaam-declaration-on-budget-transparency-accountability-and-participation/

Florini, A. (2007). The right to know: transparency for an open world. New York: Columbia Univ Press.

Fung, A. (2006). Varieties of participation in complex governance. Public Administration Review, 66, 66-75.

Fung, A., Graham, M., \& Weil, D. (2007). Full disclosure: the perils and promise of transparency. Cambridge: Cambridge University Press.

Fung, A., \& Weil, D. (2010). Open government and open society. In D. Lathrop, \& L Ruma (Eds.), Open government: collaboration, transparency, and participation (pp. 105-114). Cambridge, MA: O'Reilly.

Grigorescu, A. (2003). International organizations and government transparency: linking the international and domestic realms. International Studies Quarterly, 47(4). 643-667.

Grimmelikhuijsen, S. (2013). A good man but a bad wizard. About the limits and future of transparency of democratic governments. Information Polity, 17, 293-302.
Halachmi, A., \& Holzer, M. (2010). Citizen participation and performance measurement: operationalizing democracy through better accountability. Public Administration Quarterly, 34(3), 378-399.

Heald, D. (2006). Varieties of transparency. In C. Hood, \& D. Heald (Eds.), Transparency: the key to better govemance. Proceedings of the British Academy. (pp. 25-43). Oxford: Oxford University Press.

Heald, D. (2012). Why is transparency about public expenditure so elusive? International Review of Administrative Sciences, 78(1), 30-49.

International Budget Partnership (2010). Open Budgets, transform lives: the Open Budget Survey, International Budget Partnership (http://internationalbudget.org/what-wedo/open-budget-survey/)

International Budget Partnership (2011a). Guide to Open Budget Questionnaire: an explanation of the questions and response options. Intemational Budget Partnership, Center on Budget and Policy Priorities.

International Budget Partnership (2011b). Open Budget Questionnaire. International Budget Partnership, Center on Budget and Policy Priorities.

Khagram, S., De Renzio, P., \& Fung A. (2013). Overview and synthesis: the political economy of fiscal transparency, participation, and accountability around the world. In S. Khagram, A. Fung, \& P. De Renzio (Eds.), Open budgets: the political economy of transparency, participation, and accountability (pp. 1-50). Washington: Brookings Institution Press.

Kolstad, I., \& Wiig, A. (2009). Is transparency the key to reducing corruption in resourcerich countries? World Development, 37(3), 521-532.

Kweit, M. G., \& Kweit, R. W. (1981). Implementing citizen participation in a bureaucratic society: a contingency approach. Praeger New York.

Lambsdorff.J. G. (2006). Causes and consequences of corruption: what do we know from a cross-section of countries? In S. Rose-Ackerman (Ed.), International handbook on the economics of corruption (pp. 3-51). Cheltenham, UK: Edward Elgar.

Lerner, J. (2011, Summer). Participatory budgeting: building community agreement around tough budget decisions. National Civic Review, 30-35.

Lerner, J. (2012). By the people, for the people: participatory budgeting from the bottom up in North America. Journal of Public Deliberation, 8(2) (Article 2).

Louren o, R. P. (2013). Data disclosure and transparency for accountability: a strategy and case study. Information Polity, 18, 243-260.

Margetts, H. (2006). Transparency and digital government. In C. Hood, \& D. Heald (Eds.), Transparency: the key to better governance. Proceedings of the British Academy. (pp. 197-207). Oxford: Oxford University Press.

Masud. H. (2011). Is there hope for budget transparency? Findings from the Open Budget Survey 2010. International Journal of Government Financial Management, 11(1), 43.

McGee, R., \& Gaventa, J. (2011). Shifting power? Assessing the impact of transparency and accountability initiatives. IDS Working Papers, 383, 1-39.

Michener, G., \& Bersch, K. (2013). Identifying transparency. Information Polity, 18, 233-242.

Norris, Pippa (2001). Digital divide: civic engagement, information poverty and the intemet worldwide. Cambridge: Cambridge University Press, 105.

Obama, B. (2009). Transparency and Open Government: Memorandum for the Heads of Executive Departments and Agencies. http://www.whitehouse.gov/thepressoffice/ TransparencyandOpenGovernment/ (Accessed: 02-10-2011)

OECD (2001). Citizens as partners: information, consultation, and public partnerships in policy making. OECD (Available at: http://www.ecnl.org/dindocuments/214_OECD Engaging\%20Citizens\%20in\%20Policy-Making.pdf).

OECD (2002). Best practices for budget transparency. Paris: OECD.

Peixoto, T. (2009, March). Beyond theory: e-participatory budgeting and its promises for eparticipation. European Joumal of ePractice, 7, 1-9.

Pérez, C. C., Hernandez, A. M.., \& Bolivar, M. P. (2005). Citizens' access to on-line governmental financial information: practices in the European Union countries. Government Information Quarterly, 22(2), 258-276.

Rios, A. M., Benito, B., \& Bastida, F. (2013). Determinants of central government budget disclosure: an international comparative analysis. Journal of Comparative Policy Analysis, 15(3), 235-254.

Rosendorff, B. P., \& Vreeland, J. R. (2006). Democracy and data dissemination: the effect of political regime on transparency. New York University and Yale University (Retrieved from http://homepages.nyu.edu/bpr1/papers/BPRJRV.pdf)

Ross, M. (2011). Mineral wealth and budget transparency. IBP working paper 2 . Washington: International Budget Partnership.

Sayogo, D. S., \& Harrison, T. (2013). Exploring the socio-political determinants of open budget: a cross national perspective. In J. R. Gil-Garcia (Ed.), Egovernment success factors and measures: theories, concepts, and methodologies. IGI Global.

Seifert, J., Carlitz, R., \& Mondo, E. (2013). The Open Budget Index (OBI) as a comparative statistical tool. Journal of Comparative Policy Analysis, 15, 87-101.

Sharma, B. (2008). Voice, accountability, and civic engagement: a conceptual overview. UNDP Oslo Governance Centre.

Sirianni, C. (2009). Investing in democracy: engaging citizens in collaborative governance. Washington DC: Brookings Institution Press.

Sunlight Foundation (2013). Sunlight agenda: 2013. http://sunlightfoundation.com/ policy/agenda/ (Accessed: 2013-02-15)

Torres-Reyna, O. (2007). Linear regression using Stata. Statistic HandoutPrinceton University (http://dss1.princeton.edu/training/).

Tyler, T. (1998). Trust and democratic governance. In V. V. A. Braithwaite, \& M. Levy (Eds.), Trust \& govemance (pp. 269-294). New York: Russell Sage Foundation.

Wehner, J., \& De Renzio, P. (2013). Citizens, legislators, and executive disclosure: the political determinants of fiscal transparency. World Development, 41. 96-108. 
Williams, C. B., Gulati, G. J., \& Yates, D. J. (2013). Predictors of on-line services and e-participation: a cross national comparison. In L. F. Luna-Reyes, \& J. Zhang (Eds.), Proceedings of the 14th Anmual International Conference on Digital Government Research. Digital Government Society.

Wong, W., \& Welch, E. (2004). Does e-govemment promote accountability? A comparative analysis of website openness and government accountability. Governance, 17(2). 275-297.

Teresa M. Harrison is a Professor in the Department of Communication and a Faculty Fellow at the Center for Technology in Government, both at the University at Albany, Albany, New York, USA. Her research interests focus on new media technologies and their impact on community, democratic practices, and government.
Djoko Sigit Sayogo is an Assistant Professor at the Department of Economics, the University of Muhammadiyah at Malang, Indonesia. He received his doctorate from the Rockefeller College of Public Administration and Policy, the University at Albany. SUNY in 2013. He is the recipient of Fulbright Presidential Scholarship in 2008 from Indonesia. His research interests include public sector accounting, e-government, collaborative networks, data sharing, and smart disclosure policy. 
Transparency, participation, and accountability practices in open government: A comparative study

\section{ORIGINALITY REPORT}

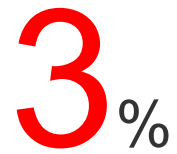

SIMILARITY INDEX
$1 \%$

INTERNET SOURCES
$2 \%$

PUBLICATIONS
$1 \%$

STUDENT PAPERS

Loni Hagen, Teresa M. Harrison, Özlem Uzuner, William May, Tim Fake, Satya Katragadda. "E-petition popularity: Do linguistic and semantic factors matter?", Government Information Quarterly, 2016

Publication

2 Submitted to Centro Supperior de Hosteleria de Galicia Student Paper

3 www.emeraldinsight.com Internet Source

4 Stamati, Teta, Thanos Papadopoulos, and

Dimosthenis Anagnostopoulos. "Social media for openness and accountability in the public sector: Cases in the Greek context", Government Information Quarterly, 2015. Publication 
